\title{
Functional Properties of Oleoresin Extracted from White Pepper (Piper nigrum L.) Retting Waste Water
}

(Sifat Kefungsian Oleoresin Diekstrak daripada Air Sisa Rendaman Lada Putih (Piper nigrum L.))

\author{
NURUl SHAHIRAH AZIZ, NOOR-SOFFALINA SOFIAN-SENG \& WAN AidA WAN MUSTAPHA*
}

\begin{abstract}
This study was carried out to determine the antioxidant activity, total phenolic content (TPC) and piperine in oleoresin extract of pepper retting waste water. Fresh pepper berries were soaked in distilled water (1:2 w/w) and allowed to ret at four different temperatures: $28,35,42$ and $49^{\circ} \mathrm{C}$ for a total of 16 days. The retting waste water was collected on the 4 th, 8th, 12th and 16th day and was then subjected to dichloromethane liquid extraction prior to analyses. The results showed that highest $(\mathrm{p}<0.05)$ oleoresin yield $(271.34 \pm 28.09 \mathrm{mg} / \mathrm{g})$, antioxidant activity in DPPH $(84.58 \pm 4.93 \%)$, FRAP assay (49.55 $\pm 6.11 \mathrm{mM} \mathrm{TE} / \mathrm{g})$ and total phenolic content (5.64 $\pm 0.06 \mathrm{mg}$ GAE $/ \mathrm{g})$ obtained at low temperature and shorter days of retting $\left(28^{\circ} \mathrm{C}\right.$, day 4$)$. Whilst at high temperature with longer days of retting $\left(49^{\circ} \mathrm{C}\right.$, day 16$)$ resulted in significantly higher $(\mathrm{p}<0.05)$ piperine content $(1.81 \pm 0.44 \%)$ in the waste water. Thus, the findings showed that the agro-industrial waste water produced during white pepper processing contain valuable bioactive oleoresins and other functional compounds which could be explored in details.
\end{abstract}

Keywords: Agro-industrial waste; antioxidant activity; pepper retting water; phenolic content; piperine

\section{ABSTRAK}

Kajian ini dijalankan untuk menentukan aktiviti antioksidan, jumlah kandungan fenolik (TPC) dan piperina ekstrak oleoresin daripada air sisa rendaman lada. Buah lada segar direndam dalam air suling (1:2 w/w) dan dibiarkan mereput pada empat suhu berbeza iaitu 28, 35, 42 dan $49^{\circ} \mathrm{C}$ selama 16 hari. Persampelan air sisa rendaman telah diambil pada hari ke 4, 8, 12 dan 16 sepanjang proses pereputan untuk analisis lanjut. Keputusan kajian menunjukkan air sisa rendaman pada suhu yang rendah dan hari rendaman yang lebih pendek $\left(28^{\circ} \mathrm{C}, 4\right.$ hari), menunjukkan kandungan oleoresin (271.34 $\pm 28.09 \mathrm{mg} / \mathrm{g}$ ), aktiviti antioksida tertinggi bagi ujian DPPH $(84.58 \pm 4.93 \%)$ dan FRAP (49.55 \pm 6.11 mM TE/g) dan jumlah kandungan fenolik (5.64 $\pm 0.06 \mathrm{mg} \mathrm{GAE} / \mathrm{g})$ yang paling tinggi ( $<<0.05)$. Walau bagaimanapun, pada suhu tinggi dengan hari rendaman yang lebih lama $\left(49^{\circ} \mathrm{C}, 16\right.$ hari) tetap bermanfaat kerana menunjukkan kandungan piperina yang tinggi $(1.81 \pm 0.44 \%$; p $<0.05)$ dalam air sisa. Oleh itu, penemuan kajian ini menunjukkan bahawa sisa agro-industri semasa penghasilan lada putih iaitu air sisa rendaman mempunyai bahan oleoresin dan sebatian aktif lain yang boleh diteroka untuk kajian lanjut.

Kata kunci: Aktiviti antioksidan; kandungan fenolik; piperina; rendaman air lada; sisa agro-industri

\section{INTRODUCTION}

The pepper (Piper nigrum L.) plant is where black pepper and white pepper are derived from. Compared to black pepper that only requires sun drying of the harvested pepper berries, white pepper production requires additional processes to decorticate the pepper outer pericarp (Vinod et al.2014). The most common practice is via water retting method in which the pepper berries are immersed in water; either in river, small lakes or soaked in containers for a maximum of 8 to 15 days (Parthasarathy et al. 2007; Zachariah 2008). This is carried out in order to allow natural enzymes produced by the microflora present in the water and on the pepper berries to degrade and weaken the pepper pericarp cell wall (Akin 2010; Sivakumaar et al. 2010).

The amount of water used for the retting process is usually two to three times the weight of pepper berries and if carried out using still water in containers, the water need to be changed every 2 to 3 days to prevent malodour due to the production of methylphenol and methylindole (Horne 2012; Steinhaus \& Schieberle 2005). This large volume of water is always discarded after sufficient retting has been performed. The pepper berries obtained after the retting are rubbed or trampled to remove the soft and rotted pericarp from the pepper core which is the white pepper. Often, the retting water and pericarp waste from this process are released into natural watercourse such as the river and is considered an environmental pollution.

Due to the prolong soaking of pepper berries during the water retting process, there are possibilities that the bioactive compounds and organic matter naturally present in pepper such as oleoresins (containing piperine and phenolic compounds) may have leached out into the soaking water. Oleoresin is a lipophilic mixture containing 
volatile and non-volatile component that deliver the aroma and pungency characteristics of pepper (Premi 2000). The quality of pepper oleoresin depends on the volatile oil, piperine and other non-volatile constituents. Piperine is a bioactive compound due to its effects on cells and tissues of living organism. This naturally occurring alkaloid has demonstrated plenty of beneficial health and therapeutic effects (Gorgani et al. 2017). Piperine found in pepper Piper nigrum has major pharmacological impacts on neuromuscular systems, exercises sedative effect and helps in digestion (Andrade \& Ferreira 2013). It also reported to have immunomodulatory, anti-carcinogenic, anti-asthmatic, stimulatory, hepatoprotective, antiinflammatory antimicrobial and anti-ulcer activities (Bai \& Xu 2000; Darshan \& Doreswamy 2004; Yang et al. 2002). Pepper has been widely reported to possess radical scavenging activities and phenolic compounds (Lu et al. 2011). The presence of plant polyphenols as functional compounds supplies dietary antioxidants and helps in human health by reducing disease risks (Arcaro et al. 2014; Meghwal \& Goswami 2013). Currently there is no study done to investigate the active compound in retting waste water. The extraction of bioactive and functional components present in agro-industrial waste supports greener and sustainable process and the recovered compounds can be utilized as drugs, functional food ingredients or nutraceuticals (Joana Gil-Chávez et al. 2013; Kumar et al. 2017). Hence, this study aimed to evaluate the presence of the bioactive and functional compounds in the pepper retting waste water at different temperatures and days.

\section{MATERIALS AND METHODS}

\section{SAMPLE PREPARATION}

Retting of pepper berries in water $(1: 2 \mathrm{w} / \mathrm{w})$ was carried out in conical flasks placed in a temperature controlled shaking water bath at $28,35,42$ and $49^{\circ} \mathrm{C}$. Retting waste water was changed daily to avoid microbial contamination and spoilage. The retting waste water were collected at 4, 8, 12 and 16 days and kept in seal bag at $-4^{\circ} \mathrm{C}$ before subjected to dichloromethane (DCM) liquid extraction.

\section{EXTRACTION OF OLEORESIN}

Water sample $(80 \mathrm{~mL})$ was filtered by using filter paper (Whatman No. 1, $11 \mu \mathrm{m}$ ) before being poured into separatory funnel and added with $5 \mathrm{~mL}$ of saturated sodium chloride $(\mathrm{NaCl})$. Fifteen $\mathrm{mL}$ of dichloromethane (DCM) was gradually added and mixture was gently shaken for about 3 min before resting. The step was repeated two times with addition of $15 \mathrm{~mL}$ DCM. DCM layer with small amount of emulsion was then removed into clean $125 \mathrm{~mL}$ conical flask and anhydrous sodium sulfate was added to dry the solution. Extractant was then evaporated using rotatory evaporator at $50^{\circ} \mathrm{C}$ for $25 \mathrm{~min}$ and the weight recorded as oleoresin yield and kept at $-18^{\circ} \mathrm{C}$ until further analyses.

\section{FREE RADICAL SCAVENGING ACTIVITY (DPPH) ASSAY}

DPPH was prepared in methanol to give a $0.15 \mathrm{mM}$ solution and $2.9 \mathrm{~mL}$ DPPH was allowed to mix with $100 \mu \mathrm{L}$ sample. Solution was kept in dark for $30 \mathrm{~min}$. Amount of $300 \mu \mathrm{L}$ solution was pipetted into 96-well plat and was read at 517 using spectrophotometer (BioTek Epoch). The result was expressed as percent of radical scavenging activity; where A1 is the absorbance of the DPPH blank and A2 is the absorbance of the sample with DPPH. Reading was blanked with methanolic solution of DPPH.

$$
\begin{aligned}
& \% \text { Free radical } \\
& \text { scavenging activity }
\end{aligned}=\frac{(\mathrm{A} 1-\mathrm{A} 2)}{\mathrm{A} 1} \times 100
$$

\section{FERRIC REDUCING ANTIOXIDANT POWER (FRAP) ASSAY}

FRAP assay was conducted according to Benzie and Strain (1996) with modification. The FRAP reagent consists of 10 $\mathrm{mM}$ TPTZ solution in $40 \mathrm{mM} \mathrm{HCl}, 20 \mathrm{mM} \mathrm{FeCl}_{3}$ solution and $0.3 \mathrm{M}$ acetate buffer (pH3.6) in proportions of $1: 1: 10$ $(\mathrm{v} / \mathrm{v} / \mathrm{v})$. One $\mathrm{mL}$ of sample was mixed with $2 \mathrm{~mL}$ of freshly prepared FRAP reagent and the reactive mixture was incubated in the dark for $30 \mathrm{~min}$. The absorbance was measured at $593 \mathrm{~nm}$ using a UV spectrophotometer. Standard curve of 5, 10, 15, 20 and 25 ppm were made with Trolox and the results were expressed as $\mathrm{mM} \mathrm{TE} / \mathrm{g}$ in Trolox equivalents.

\section{TOTAL PHENOLIC COUNT (TPC)}

Phenolic content was measured using Folin-Ciocalteu method. One $\mathrm{mL}$ of sample extract was added to $5 \mathrm{~mL}$ of Folin-Ciocalteu reagent and $4 \mathrm{~mL}$ solution of $7.5 \%$ $\mathrm{Na}_{2} \mathrm{CO}_{3}$. After 90 min of incubation $200 \mu \mathrm{L}$ was pipetted into 96 well plate and measured at $760 \mathrm{~nm}$ absorbance by BioTek Epoch microplate spectrophotometer. Standard curve of Gallic acid was done at concentration of 1 - 50 ppm and phenolic activity was determined and expressed as mg Gallic acid equivalent (GAE)/g.

\section{PIPERINE DETERMINATION}

Two $\mathrm{mL}$ of sample extract was filtered using disposable microfilter $(0.22 \mu \mathrm{m})$ into HPLC amber vial and $20 \mu \mathrm{L}$ of the diluent was injected into HPLC equipped with a Photodiode Array Detector (Waters, 2998). Column used was Water XBridge (C18 $4.6 \times 150 \mathrm{~mm}, 4.5 \mu \mathrm{m})$ with flow rate of 1 $\mathrm{mL} \mathrm{min}^{-1}$ and mobile phase of methanol: deionized water (2.3:1). Piperine analytical standard (Sigma Aldrich) was prepared at $1,2,4,6,8$ and $10 \mathrm{ppm}$ in $95 \%$ methanol to establish the standard curve.

\section{STATISTICAL ANALYSIS}

All analyses were performed in triplicate $(n=3)$ and data obtained were reported as mean \pm standard deviation. One way ANOVA was carried out to compare the difference in the 
mean values, whereby means were considered significant if $p<0.05$. Pearson's correlation was carried out to investigate the correlation between oleoresin yield, DPPH, FRAP, TPC and piperine content. All statistical analyses were carried out using SPSS statistical package version 22.

\section{RESULTS AND DISCUSSION}

\section{YIELD OF OLEORESIN}

Pepper oleoresins extracted by using solvent possess flavour profile similar to freshly ground black pepper. Due to the ease of handling as well as free from microbial contamination and deterioration the oleoresins have the potential application as natural flavouring substances in food (Srinivasan 2007). Figure 1 shows the oleoresin extracted from retting waste water accumulated at different days and temperature. Oleoresin from day 4 $\left(28^{\circ} \mathrm{C}\right)$ gives highest yield $(p<0.05)$ compared to other days and temperature with $271.34 \pm 28.09 \mathrm{mg} / \mathrm{g}$. Most of the leaching out happened during the earlier days and lower temperature retting as the amount of oleoresin is significantly higher $(p<0.05)$ on day 4 of temperature 28 and $35^{\circ} \mathrm{C}$ compared to other days. It is also postulated that the oleoresin yield may be higher if the waste water was collected in beginning of retting day of 1,2 and 3 . From the previous study, oleoresin extracted from black pepper has been reported to be in the range 5-15\% (Shaikh et al. 2006). Retting at higher temperature may affect the yield of oleoresin obtained since the oleoresin compound is sensitive to heat, light and oxygen (Shaikh et al. 2006). Pearson correlation in Table 1 shows that oleoresin content in waste water is positively correlated with antioxidant activity DPPH $(r=0.877, p<0.01)$, FRAP $(r=0.819, p<0.01)$ and total phenolic content $(r=0.902$, $p<0.01)$. This shows that extracted oleoresin in the waste water still contain important antioxidant and phenolic compounds as it leach out from the pepper pericarp.

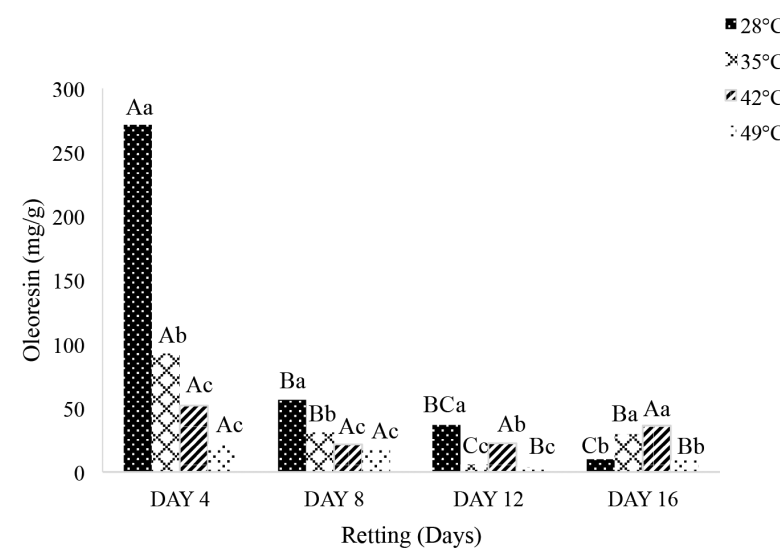

${ }^{\mathrm{A}-\mathrm{B}}$ Means \pm standard error with different uppercase letters are significantly different $(p<0.05)$ at the same temperature of different retting days

${ }^{a-b}$ Means \pm standard error with different lowercase letters are significantly different $(p<0.05)$ on the same day at different retting temperature

FIGURE 1. Oleoresin yield extracted from pepper retting waste water at different retting temperature and days

\section{ANTIOXIDATIVE ACTIVITY}

\section{FREE RADICAL SCAVENGING ACTIVITY ASSAY}

DPPH or 1, 1 Diphenyl 2- Picryl Hydrazyl assay is widely used to test the free radical scavenging activity of plant extract. The antioxidant activity of retting waste water was tested by the ability of the extract to inhibit stable free radical DPPH. Figure 2 shows the DPPH scavenging activity of retting waste water on day 4 at $28^{\circ} \mathrm{C}$ was significantly highest $(p<0.05)$ at $84.58 \pm 4.93 \%$. High value of DPPH in retting waste water suggested that the functional components from the pepper berries skin or pericarp might have leached out into the water due to the degradation of the pericarp cell wall during earlier days of retting process. Gülçin (2005) reported DPPH radical scavenging activity of 55 and $48 \%$ in water and ethanol extracts of black pepper respectively compared to their BHT

TABLE 1. Pearson correlation between antioxidant activity, total phenolic content, piperine content and oleoresin yield obtained from pepper retting waste water

\begin{tabular}{|c|c|c|c|c|c|c|}
\hline & & Oleoresin & DPPH & FRAP & TPC & Piperine \\
\hline Oleoresin & $\begin{array}{l}\text { Pearson Correlation, } r \\
\text { Sig. (2-tailed), p }\end{array}$ & & $\begin{array}{l}0.877 * \\
0.000\end{array}$ & $\begin{array}{l}0.819^{*} \\
0.000\end{array}$ & $\begin{array}{l}0.902^{*} \\
0.000\end{array}$ & $\begin{array}{r}-0.363 \\
0.160\end{array}$ \\
\hline DPPH & $\begin{array}{l}\text { Pearson Correlation, } r \\
\text { Sig. (2-tailed), p }\end{array}$ & $\begin{array}{l}0.877^{*} \\
0.000\end{array}$ & & $\begin{array}{l}0.625^{*} \\
0.002\end{array}$ & $\begin{array}{l}0.875^{*} \\
0.000\end{array}$ & $\begin{array}{r}-0.407 \\
0.067\end{array}$ \\
\hline FRAP & $\begin{array}{l}\text { Pearson Correlation, } r \\
\text { Sig. (2-tailed), p }\end{array}$ & $\begin{array}{l}0.819^{*} \\
0.000\end{array}$ & $\begin{array}{l}0.625^{*} \\
0.002\end{array}$ & & $\begin{array}{l}0.820^{*} \\
0.000\end{array}$ & $\begin{array}{r}-0.094 \\
0.687\end{array}$ \\
\hline TPC & $\begin{array}{l}\text { Pearson Correlation, } r \\
\text { Sig. (2-tailed), p }\end{array}$ & $\begin{array}{l}0.902^{*} \\
0.000\end{array}$ & $\begin{array}{l}0.875^{*} \\
0.000\end{array}$ & $\begin{array}{l}0.820^{*} \\
0.000\end{array}$ & & $\begin{array}{r}-0.191 \\
0.394\end{array}$ \\
\hline Piperine & $\begin{array}{l}\text { Pearson Correlation, } r \\
\text { Sig. (2-tailed), p }\end{array}$ & $\begin{array}{r}-0.363 \\
0.160\end{array}$ & $\begin{array}{r}-0.407 \\
0.067\end{array}$ & $\begin{array}{r}-0.094 \\
0.687\end{array}$ & $\begin{array}{r}-0.191 \\
0.394\end{array}$ & \\
\hline
\end{tabular}

*Correlation is significant at the 0.01 level (2-tailed) 


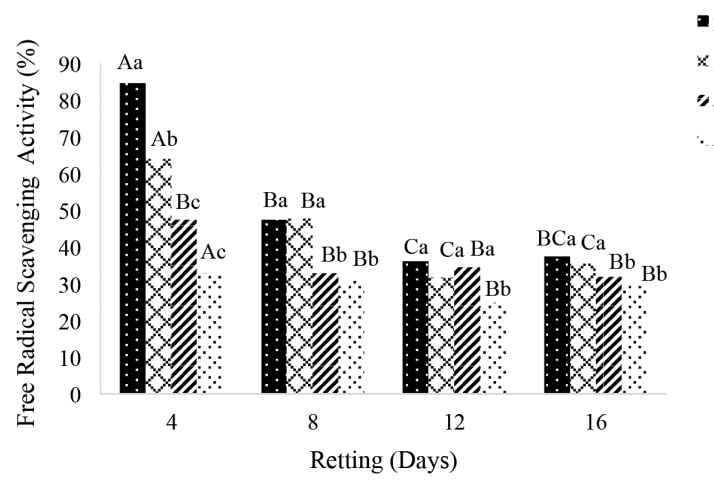

A-B Means \pm standard error with different uppercase letters are significantly different $(p<0.05)$ at the same temperature of different retting days

${ }^{\mathrm{a}-\mathrm{b}}$ Means \pm standard error with different lowercase letters are significantly different $(p<0.05)$ on the same day at different retting temperature

FIGURE 2. Free radical scavenging activity (\%) of retting waste water at different retting temperature and days

control with $76 \%$ activity. The DPPH scavenging activity started to decrease as the retting days and temperature increase; showing lower ability of antioxidant compound to scavenge the radical compound at higher temperature and longer retting day. Lowest DPPH scavenging activity was shown at temperature $49^{\circ} \mathrm{C}$; day 12 which has no significant different $(p>0.05)$ with $49^{\circ} \mathrm{C}$; day 16 and $49^{\circ} \mathrm{C}$; day 8 . This is also probably due to the significant physical changes observed on pepper berries. At high temperature retting of $49^{\circ} \mathrm{C}$ the skin of pepper berries become dark, tough and stiff. Strengthen pericarp skin of pepper berries eventually cease to release active compound into the water hence reduce the scavenging activity.

\section{FERRIC REDUCING ANTIOXIDANT POWER (FRAP) ASSAY}

In the ferric reducing antioxidant power (FRAP) assay conducted, $\mathrm{Fe}^{3+}(2,4,6 \text {-tripyridyl-s-triazine })_{2} \mathrm{Cl}_{3}$ was used as oxidant probe to measure the reducing power of antioxidant compounds. Reduced oxidant probe in the reaction will change colour and stop changing upon completion (Huang et al. 2005). Referring to Figure 3, the waste water collected exhibit highest ferric reducing capacity $(49.55 \pm 6.11$ $\mathrm{mM} \mathrm{TE} / \mathrm{g}, p<0.05$ ) at lower temperature (day $4 ; 28^{\circ} \mathrm{C}$ ) of retting equate to the result of DPPH assay. Water uptake by osmosis during the soaking of pepper berries weaken the matrix cells and cause the pericarp cells to stretched and swelled (Yadav \& Tyagi 2008). Prolong immersion in water causes the cell wall structure to be damaged and collapsed releasing various active compound into the water. Pearson correlation showed that antioxidant activity of waste water by DPPH $(r=0.877, p<0.01)$ and FRAP $(r=0.819$, $p<0.01)$ was strongly correlated with the oleoresin yield $(p<0.01)$. A significant correlation $(p<0.01)$ was observed for FRAP $(r=0.820)$ and DPPH $(r=0.875)$ assay with TPC. These results indicated the extracts from waste water exhibited a noticeable effect on scavenging free radical and was mainly contributed by the phenolic compounds (Mahdavi et al. 2017).

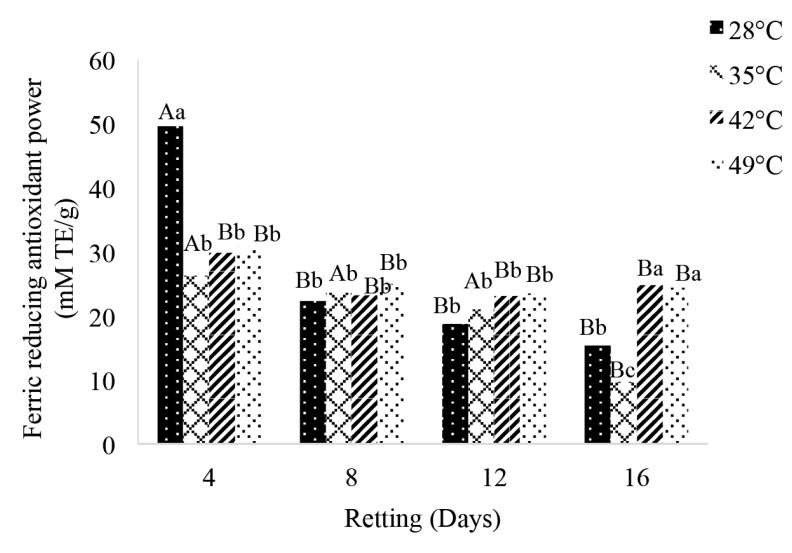

${ }^{\text {A-B }}$ Means \pm standard error with different uppercase letters are significantly different $(p<0.05)$ at the same temperature of different retting days

${ }^{\mathrm{a}-\mathrm{b}}$ Means \pm standard error with different lowercase letters are significantly different $(p<0.05)$ on the same day at different retting temperature

FIGURE 3. Ferric reducing antioxidant power in Trolox equivalent (mM TE/g) of waste water after retting process at different temperature and days

\section{TOTAL PHENOLIC CONTENT (TPC)}

Phenolic compounds are naturally found in fruits, vegetables, cereals, legumes and beverages in abundant amount (Kochhar 2016; Prakash \& Sharma 2014). Besides providing beneficial effects on the plant host, these compounds can function as free radical scavengers thus gives important biological properties in promoting human health such as anti-aging, antioxidant activity and anti-carcinogenic effects (Dai \& Mumper 2010; Działo et al. 2016; Pandey \& Rizvi 2009). Figure 4 shows the TPC in the oleoresin extracted from retting waste water (expressed as $\mathrm{mg}$ gallic acid per $\mathrm{g}$ of sample). Retting waste water on day 4 ranging from $5.64 \pm 0.06$ to $3.63 \pm 0.11 \mathrm{mg} \mathrm{GAE} / \mathrm{g}$ show a highest value $(p<0.05)$ at $28^{\circ} \mathrm{C}$ compared to other temperature tested in the same day. Significantly higher $(p<0.05)$ TPCs were obtained on day 4 compared to other days on the respective temperature. The phenolic content in retting waste water reduced as the day of retting increase for each temperature. The phenolic content in retting waste water was found to be positively correlated $(p<0.01)$ with oleoresin and DPPH activity as discussed previously. A highly positive correlation between TPC and antioxidant activity has been reported in various plant species and plant-based food products (Esmaeili et al. 2016; Wern et al. 2016). Gülçin (2005) reported 0.054 and $0.043 \mathrm{mg} / \mathrm{g}$ TPC in water extracts and ethanol extracts of black pepper, respectively. In Agbor et al. (2006) study, polyphenolic concentration of hydrolyzed and non-hydrolyzed white pepper was about $7.0-8.0$ and $5.0-6.0 \mathrm{mg} / \mathrm{g}$ catechin equivalent. Andrade and Ferreira (2013) found much higher yield of phenolics on black pepper with $27 \pm 3 \mathrm{mg} \mathrm{GAE} / \mathrm{g}$ by Soxhlet method and $26 \pm 3 \mathrm{mg} \mathrm{GAE} / \mathrm{g}$ by ultrasound method. Variyar and Bandyopadhyay (1994) earlier work has identified syringic, vanillic and ferulic acid in the 


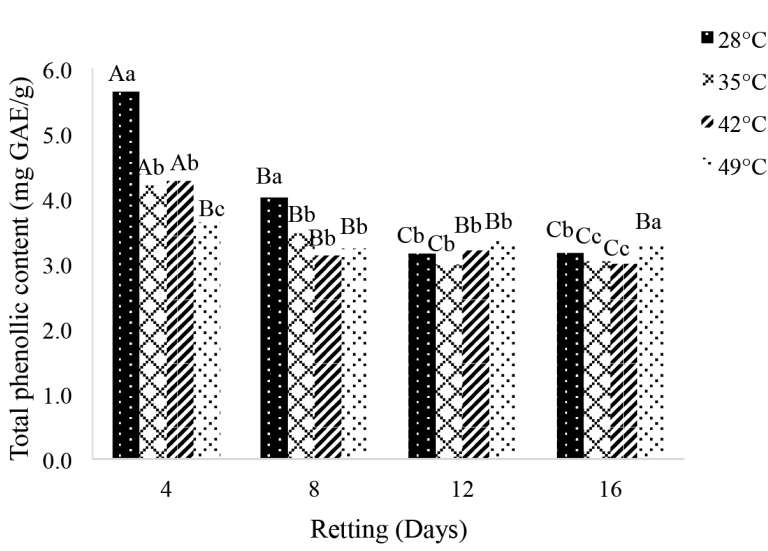

${ }^{A-B}$ Means \pm standard error with different uppercase letters are significantly different $(p<0.05)$ at the same temperature of different retting days

${ }^{\mathrm{a}-\mathrm{b}}$ Means \pm standard error with different lowercase letters are significantly different $(p<0.05)$ on the same day at different retting temperature

FIGURE 4. Total phenolic content (mg GAE/g) of waste water after retting process at different temperature and days

phenolic acid fraction. Lower temperature immersion seems to leach some of these phenolic compounds from pepper berries into the water. According to Prabhakaran Nair (2011), source of phenolic compound is from the skin of pepper berries. Pepper berries have been reported to contain 3,4-dihydroxyphenyl ethanol glucoside, 3,4-dihydroxy-6-(N-ethylamino) benzamide and phenolic acid glycosides as the main phenolic compounds (Chatterjee et al 2007; Pradhan et al. 1999). According to Chatterjee et al. (2007), among the pepper phenolics fractions 3,4-dihydroxyphenyl ethanol (hydroxytyrosol) glucoside had the highest DPPH radical scavenging activity approximately $60 \%$ higher than standard Trolox. However, these compounds are lacking in black pepper due to oxidation during drying (Variyar \& Bandyopadhyay 1994). The phenolic compounds in pepper have been reported to prevent coronary diseases and cancer, as well as age-related degenerative brain disorders, inhibit lipid peroxidation and reducing plasmid DNA damage induced by UV and gamma radiation. These effects were mainly as the consequences of the phenolic compounds ability to scavenge (Chatterjee et al 2007).

\section{PIPERINE CONTENT IN WASTE WATER}

Pepper piperine has been reported to exhibit numerous health benefits including stimulating digestive enzymes of pancreas (Tiwari \& Singh 2008), as antidiabetic (Rauscher et al. 2000), antidepressant (Li et al. 2007), antidiarrhoeal activity (Reshmi et al. 2010) and anticancer (Yaffe et al. 2015). The amount of piperine in white pepper from Piperaceae family (Piper nigrum L.) varies from $2 \%$ to $7.4 \%$ (Peter 2006; Ravindran 2003). In another report, white pepper piperine constitutes of 2.70 to $5.85 \%$ for 15 selected cultivars (Parthasarathy et al. 2007). However, there is no report on piperine percent of waste water from the retting of pepper berries. Table 2 shows days of retting had no significant $(p>0.05)$ effect whereas temperature exhibited significant $(p<0.05)$ effect on the piperine content although no apparent trend was observed. This indicates that piperine in the waste water is more temperature dependent compared to time. The highest piperine content obtained in waste water was $1.81 \pm 0.44 \%$ at $49^{\circ} \mathrm{C}$ on day 16 and was significantly different $(p<0.05)$ compared with other temperature of $28^{\circ} \mathrm{C}, 35^{\circ} \mathrm{C}$ and $42^{\circ} \mathrm{C}$ on the same day. The value of piperine found in waste water $(1.81 \pm$ $0.44 \%$ ) was lower compared to the piperine found in white pepper seed (2.70 to $5.85 \%$ ). However, this indicated that the piperine did leach out from the pepper seed during water retting. Low piperine content in water at lower temperature probably due to its low solubility in water (Chavarria et al. 2016; Gorgani et al. 2017). At $49^{\circ} \mathrm{C}$ retting temperature on each 4,8 and 16 days show higher piperine content $(p<0.05)$ compared to lower temperature retting. Meanwhile the lowest piperine content was 0.36 $\pm 0.11 \%$ at $35^{\circ} \mathrm{C}$ on day 4 . Piperine was found to have no significant $(p>0.05)$ correlation with TPC, antioxidant activity and oleoresin yield of waste water.

\section{CONCLUSION}

Waste water from the water retting process of pepper berries was found to contain amount of extractable oleoresin, exhibit antioxidant activity and phenolic compounds. Piperine was also detected in the waste water. The agro-industrial waste water from pepper industry can be potentially utilized for its bioactive components as well as serving greener and sustainable process for the environment.

TABLE 2. Piperine content (\%) in waste water after water retting process at different temperature and days

\begin{tabular}{|c|c|c|c|c|}
\hline & $28^{\circ} \mathrm{C}$ & $35^{\circ} \mathrm{C}$ & $42^{\circ} \mathrm{C}$ & $49^{\circ} \mathrm{C}$ \\
\hline Day 4 & $0.60 \pm 0.10^{\mathrm{bB}}$ & $0.36 \pm 0.11$ bB & $1.00 \pm 0.21^{\mathrm{bA}}$ & $1.41 \pm 0.24 \mathrm{bA}$ \\
\hline Day 8 & $0.99 \pm 0.13 \mathrm{bA}$ & $0.45 \pm 0.14$ bB & $0.37 \pm 0.23$ ьв & $1.39 \pm 0.23 \mathrm{bA}$ \\
\hline Day 12 & $0.91 \pm 0.16^{\mathrm{bB}}$ & $0.85 \pm 0.32$ bВ & $0.78 \pm 0.29$ вв & $1.39 \pm 0.29$ bв \\
\hline Day 16 & $0.59 \pm 0.13^{\mathrm{bB}}$ & $0.75 \pm 0.13 \mathrm{bB}$ & $0.68 \pm 0.44^{\text {ьв }}$ & $1.81 \pm 0.44^{\mathrm{bA}}$ \\
\hline
\end{tabular}




\section{ACKNOWLEDGEMENTS}

The authors would like to thank the Ministry of Education Malaysia for funding this project under research grant FRGS/1/2016/WAB01/UKM/02/2 and the School of Chemical Sciences and Food Technology, Faculty of Science and Technology, Universiti Kebangsaan Malaysia for providing the research facilities.

\section{REFERENCES}

Agbor, G.A., Vinson, J.A., Oben, J.E. \& Ngogang, J.Y. 2006. Comparative analysis of the in vitro antioxidant activity of white and black pepper. Nutrition Research 26(12): 659-663.

Akin, D.E. 2010. Flax - Structure, Chemistry, Retting and Processing in Industrial Applications of Natural Fibres: Structure, Properties and Technical Applications. London: John Wiley \& Sons.

Andrade, K.S. \& Ferreira, S.R.S. 2013. Antioxidant activity of black pepper (Piper nigrum L.) oil obtained by super critical $\mathrm{CO}_{2}$. In III Iberoamerican Conference on Super Critical Fluids Cartagena de Indias (Colombia). pp. 1-5.

Arcaro, C.A., Gutierres, V.O., Assis, R.P., Moreira, T.F., Costa, P.I., Baviera, A.M. \& Brunetti, I.L. 2014. Piperine, a natural bioenhancer, nullifies the antidiabetic and antioxidant activities of curcumin in streptozotocin-diabetic rats. PLoS One 9(12): 1-21.

Bai, Y.F. \& Xu, H., 2000. Protective action of piperine against experimental gastric ulcer. Acta Pharmacologica Sinica 21(4): 357-359.

Benzie, I.F. \& Strain, J.J. 1996. The ferric reducing ability of plasma (FRAP) as a measure of "antioxidant power": The FRAP assay. Analytical Biochemistry 239(1): 70-76.

Chatterjee, S., Niaz, Z., Gautam, S., Adhikari, S., Variyar, P.S. \& Sharma, A. 2007. Antioxidant activity of some phenolic constituents from green pepper (Piper nigrum L.) and fresh nutmeg mace (Myristica fragrans). Food Chemistry 101(2): 515-523.

Chavarria, D., Silva, T., Magalhães e Silva, D., Remião, F. \& Borges, F. 2016. Lessons from black pepper: Piperine and derivatives thereof. Expert Opinion on Therapeutic Patents 26(2): 245-264.

Dai, J. \& Mumper, R.J. 2010. Plant phenolics: Extraction, analysis and their antioxidant and anticancer properties. Molecules 15(10): 7313-7352.

Darshan,S.\& Doreswamy,R.2004.Patented antiinflammatory plant drug development from traditional medicine. Phytotherapy Research 18(5): 343-357.

Działo, M., Mierziak, J., Korzun, U., Preisner, M., Szopa, J. \& Kulma, A. 2016. The potential of plant phenolics in prevention and therapy of skin disorders. International Journal of Molecular Sciences 17(2): 1-41.

Esmaeili, A.K., Taha, R.M., Mohajer, S. \& Banisalam, B. 2016. In vitro regeneration and comparison of phenolic content, antioxidant and antityrosinase activity of in vivo and in vitro grown Asparagus officinalis. Sains Malaysiana 45(3): 373-381.

Gorgani, L., Mohammadi, M., Najafpour, G.D. \& Nikzad, M. 2017. Piperine-the bioactive compound of black pepper: From isolation to medicinal formulations. Comprehensive Reviews in Food Science and Food Safety 16(1): 124-140.

Gülçin, İ. 2005. The antioxidant and radical scavenging activities of black pepper (Piper nigrum) seeds. International Journal of Food Sciences and Nutrition 56(7): 491-499.
Horne, M.R.L. 2012. Bast fibres: Hemp cultivation and production. Handbook of Natural Fibres: Types, Properties and Factors Affecting Breeding and Cultivation. Cambridge: Woodhead Publishing Limited.

Huang, D., Ou, B. \& Prior, R.L. 2005. The chemistry behind antioxidant capacity assays. Journal of Agricultural and Food Chemistry 53(6): 1841-1856.

Joana, Gil-Chávez, G., Villa, J.A., Fernando Ayala Zavala, J., Basilio Heredia, J., Sepulveda, D., Yahia, E.M. \& González Aguilar, G.A. 2013. Technologies for extraction and production of bioactive compounds to be used as nutraceuticals and food ingredients: An overview. Comprehensive Reviews in Food Science and Food Safety 12(1): 5-23.

Kochhar, S.L. 2016. Economic Botany. 5th ed. New York: Cambridge University Press.

Kumar, S.S., Devasagayam, B., Jayashree, B. \& Kesavan, P.C. 2001. Mechanism of protection against radiation-induced DNA damage in plasmid pBR322 by caffeine. International Journal of Radiation Biology 77: 617-623.

Kumar, K., Yadav, A.N., Kumar, V., Vyas, P. \& Dhaliwal, H.S. 2017. Food waste: A potential bioresource for extraction of nutraceuticals and bioactive compounds. Bioresources and Bioprocessing 4(1): 18.

Li, S., Wang, C., Li, W., Koike, K., Nikaido, T. \& Wang, M.W. 2007. Antidepressant-like effects of piperine and its derivative antiepilepsirine. Journal of Asian Natural Products Research 9: 421-430.

Lu, M., Yuan, B., Zeng, M. \& Chen, J. 2011. Antioxidant capacity and major phenolic compounds of spices commonly consumed in China. Food Research International 44(2): 530-536.

Mahdavi, B., Yaacob, W.A. \& Din, L.B. 2017. Antioxidant and antimicrobial activity of the extracts from different parts of Etlingera sayapensis (Zingiberaceae). Sains Malaysiana 46(9): 1565-1571.

Meghwal, M. \& Goswami, T.K. 2013.Piper nigrum and piperine: An update. Phytotherapy Research 27(8): 1121-1130.

Pandey, K.B. \& Rizvi, S.I. 2009. Plant polyphenols as dietary antioxidants in human health and disease. Oxidative Medicine and Cellular Longevity 2(5): 270-278.

Parthasarathy, V.A., Sasikumar, B., Nair, R.R. \& George, K.J. 2007. Black Pepper: Botany and Horticulture in Horticultural Reviews. New York: Wiley \& Sons.

Prabhakaran Nair, K.P. 2011. Agronomy and Economy of Black Pepper and Cardamom: The "king" and "queen" of Spices. London: Elsevier.

Peter, K.V. 2006. Handbook of Herbs and Spices. Sawston, UK: Woodhead Publishing.

Pradhan, K.J., Variyar, P.S. \& Bandekar, J.R. 1999. Antimicrobial activity of novel phenolic compounds from green pepper berries (Piper nigrum L.). LWT-Food Science and Technology 32(2): 121-123.

Prakash, D. \& Sharma, G. 2014. Phytochemicals of Nutraceutical Importance. United Kingdom: CAB International.

Premi, B.P. 2000. Essential oils and oleoresins in India. Beverage and Food World 27(4): 12-19.

Rauscher, F.M., Sanders, R.A. \& Watkins, J.B. 2000. Effects of piperine on antioxidant pathways in tissues from normal and streptozotocin induced diabetic rats. Journal of Biochemical and Molecular Toxicology 14(6): 329-334.

Ravindran, P. 2003. Black Pepper: Piper nigrum. Boca Raton: CRC Press. 
Reshmi, S.K., Sathya, E. \& Devi,P.S. 2010. Isolation of piperdine from Piper nigrum L. and its antiproliferative activity. African Journal Pharmacy and Pharmacol. 4(8): 562-573.

Shaikh, J., Bhosale, R. \& Singhal, R. 2006. Microencapsulation of black pepper oleoresin. Food Chemistry 94(1): 105-110.

Sivakumaar, P.K., Sukesh, K. \& Joe, M.M. 2010. Textile Microbiology in an Introduction to Industrial Microbiology. New Delhi: S. Chand \& Company Ltd.

Srinivasan, K. 2007. Black pepper and its pungent principlepiperine: A review of diverse physiological effects. Critical Reviews in Food Science and Nutrition 47(8): 735-748.

Steinhaus, M. \& Schieberle, P. 2005. Characterization of odorants causing an atypical aroma in white pepper powder (Piper nigrum L.) based on quantitative measurements and orthonasal breakthrough thresholds. Journal of Agricultural and Food Chemistry 53(15): 6049-6055.

Tiwari, P. \& Singh, D. 2008. Anti-trichomonas activity of Sapindus saponins, a candidate for development as microbicidal contraceptive. Journal of Antimicrobial Chemotherapy 62(3): 526-534.

Variyar, P.S. \& Bandyopadhyay, C. 1994. Estimation of phenolic compounds in green pepper berries (Piper nigrum L.) by high-performance liquid chromatography. Chromatographia 39(11-12): 743-746.

Vinod, V., Kumar, A. \& Zachariah, T.J. 2014. Isolation, characterization and identification of pericarp-degrading bacteria for the production of off odour free white pepper from fresh berries of Piper nigrum L. Journal of Applied Microbiology 116(4): 890-902.

Wern, K.H., Haron, H. \& Keng, C.B. 2016. Comparison of total phenolic contents (TPC) and antioxidant activities of fresh fruit juices, commercial $100 \%$ fruit juices and fruit drinks. Sains Malaysiana 45(9): 1319-1327.
Yadav, P.R. \& Tyagi, R. 2008. Cell Culture. New Delhi, India: Discovery Publishing House.

Yaffe, P.B., Coombs, P.M.R., Doucette, C.D., Walsh, M. \& Hoskin, D.W. 2015. Piperine, an alkaloid from black pepper, inhibits growth of human colon cancer cells via G1 arrest and apoptosis triggered by endoplasmic reticulum stress. Molecular Carcinogenesis 54(10): 1070-1085.

Yang, Y.C., Lee, S.G., Lee, H.K., Kim, M.K., Lee, S.H. \& Lee, H.S. 2002. A piperidine amide extracted from Piper longum L. fruit shows activity against Aedes aegypti mosquito larvae. Journal of Agricultural and Food Chemistry 50(13): 3765-3767.

Zachariah, J. 2008. Production of White Pepper through Fermentation Technology. Indian Institute of Spices Research, Calicut.

School of Chemical Sciences and Food Technology

Faculty of Science and Technology

Universiti Kebangsaan Malaysia

43600 UKM Bangi, Selangor Darrul Ehsan

Malaysia

*Corresponding author; email: wanaidawm@ukm.edu.my

Received: 16 March 2018

Accepted: 1 June 2018 